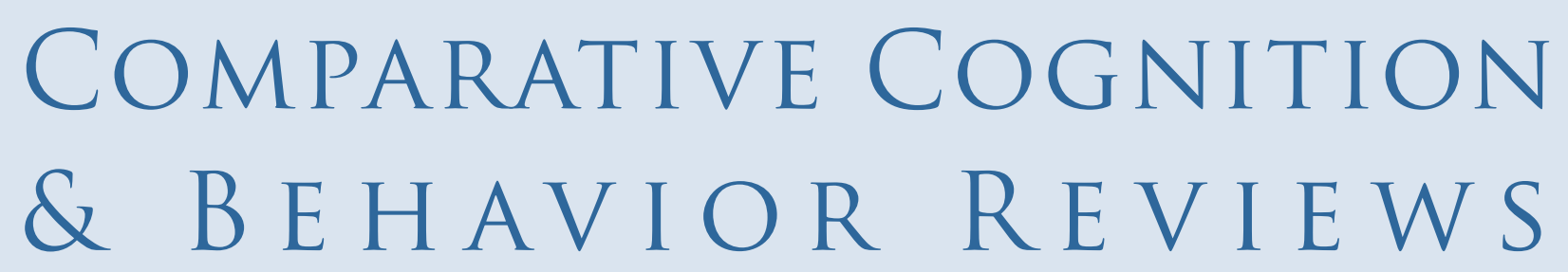

\title{
Crocodilians Are Promising Intermediate Model Organisms for Comparative Perception Research
}

\author{
Stephan A. Reber \\ Lund University
}

Crocodilians are the closest living relatives of birds and share many ecological challenges with mammalian apex predators. They evolved perception pathways that share similarities with both taxa, birds and mammals. Due to their position in the tree of life, crocodilians therefore represent a promising intermediate model for comparative research. In this review, the different modalities of perception in crocodilians are discussed: vision, audition, olfaction, gustation, sense of touch, and (the potential for) magnetoreception. The anatomy and physiology of the sensory organs are briefly described, and behavioral studies on perception summarized. Throughout the review, the similarities and differences between crocodilians and other vertebrate taxa are addressed. Overall, crocodilian sensory organs seem to have evolved for a terrestrial environment, as their eyes are adapted for vision in air, their hearing resembles that of birds, and they do not seem to use olfaction under water. A clear exception are the integumentary sensory organs, which allow them to perceive minute water movements. While crocodilian sensory organs have received quite some attention, there are relatively few behavioral studies on perception. Future research on the perceptual capacities of crocodilians will provide insight into the evolutionary origins of perception in all amniotes.

Keywords: crocodilian, vision, communication, olfaction, integumentary sensory organ

\section{Introduction}

Comparative research has started to take important steps toward truly understanding the evolution of cognition by studying an increasingly more diverse selection of taxa (Shettleworth, 2009). Nonhuman primates and classic laboratory model organisms, such as rats and pigeons, still receive most attention. But there are also many studies on other mammals and birds, mainly corvid and parrot species. A number of cognitive capacities that are deemed more advanced (mainly because they resemble typically human capacities) were found in both primates and corvids (Kabadayi \& Osvath, 2017). The ancestors of the recent primates and corvids might have shared similar challenges in their social and nonsocial environments that selected for similar capacities to cope with them (Seed, Emery, \& Clayton, 2009). While it is highly probable that convergence is responsible for these similarities, it is not clear from what substrate they evolved. Advanced cognitive capacities build on several individual traits that also could be shared via common descent between mammals and birds. For instance, the different pathways of perception are such building blocks necessary for higher cognitive functions. Studying the evolutionary origins of perception in mammals and birds is challenging, as they shared a common ancestor more than 
300 million years ago (Hugall, Foster, \& Lee, 2007). They also have drastically different overall brain structures, but there is evidence for deep homologies at the neurological level (Güntürkün, 2005; Jarvis et al., 2005; Scharff \& Petri, 2011). To understand the evolution of individual traits, one can look at other prominent branches in the amniote tree of life. The nonavian reptiles are good candidates for the study of cognitive evolution (Kis, Huber, \& Wilkinson, 2015; Wilkinson, Kuenstner, Mueller, \& Huber, 2010), and among them is a taxonomic order with a lot of potential for comparative research: the crocodilians.

Crocodilians are the closest living relatives of birds (Hugall et al., 2007), and they shared a common ancestor 250 million years ago (Nesbitt, 2011). To put this in perspective, this was still 50 million years before the direct human ancestor stopped laying eggs (Luo, 2007). Crocodilians have an avian-like brain structure (Vergne, Pritz, \& Mathevon, 2009), but in many aspects of their life history they rather resemble certain mammals, as they are quadrupedal large apex predators. In many respects, crocodilians are an intermediate model organism for comparative research. To illustrate that, let us look at acoustic communication: Acoustic perception of crocodilians is extremely similar to that of birds (Vergne et al., 2009), but they have no syrinx and produce their sounds with a larynx homologous to mammals (Reese, 1945). This intermediate model should not be confused with an outgroup. Amphibians are the outgroup for amniotes (birds, mammals, nonavian reptiles), but they lack vocal tract resonances (Rand \& Dudley, 1993), which are a key feature in all of amniote communication. Hence, studies on crocodilians can shed light on the origins of aspects in mammalian and avian communication.

All species commonly referred to as crocodilians belong to the order Crocodylia and are divided into three families with extant members: the alligators and caimans (Alligatoridae), the gharials (Gavialidae), and the "true" crocodiles (Crocodylidae). Currently,

Author Note: Stephan A. Reber, Cognitive Science, Lund University, Helgonavägen 3, Box 192, 22100 Lund, Sweden.

Correspondence concerning this article should be addressed to Stephan A. Reber at stephan.reber@lucs.lu.seor mail@stephanreber.com.

Acknowledgments: I would like to thank Anna Wilkinson (co-editor of CCBR), an anonymous reviewer, and Nicolas Mathevon for their comments on the manuscript.
28 species are recognized (Murray, Russo, Zorrilla, \& McMahan, 2019; Stevenson, 2019). The interrelatedness of these species is a very active field of study, but there is general agreement that all extant crocodilians are monophyletic. The Alligatoridae diverged first, approximately 70 million years ago, and the Crocodylidae and Gavialidae split around 25 million years later (Grigg \& Kirshner, 2015; Shirley, Vliet, Carr, \& Austin, 2013). Hence, in stark contrast to commonly held beliefs, crocodilians are not "living fossils." In fact, the recent crocodilians are younger than most other living vertebrate taxa.

All crocodilians are semiaquatic and spend a large part of their life floating at the boundary between water and air (Grigg \& Kirshner, 2015). Because they are ambush predators, most of their body remains hidden under water. However, their sensory organs commonly stay in air. Their nostrils, eyes, and ears are all arranged in a straight line on top of the skull and run almost perfectly parallel to the water surface (Figure 1A). Crocodilians have a secondary palate and can breathe freely with their mouth under water. At the back of their buccal cavity, the massive tongue is connected to the basihyoid cartilage, which is framed by epithelium and connective tissue (Britton, 2001). This structure, the "palatal valve," can be lifted up and pressed against the "palatal fold," the posterior end of the secondary palate, which is equally extended by connective tissue (Figure 1C). This mechanism prevents water from entering the pharyngeal cavity, where the glottis lies embedded in the basihyoid. All these anatomical features already indicate that crocodilian sensory organs mainly evolved to perceive airborne cues despite their semiaquatic life history. An exception might be their adaptations for perception of touch (see below).

In general, crocodilian sensory organs are well studied. However, to date, the actual perceptual capacities of crocodilians remain poorly understood. More research, particularly behavioral experiments, are required to fully understand crocodilian perception. For instance, there are histological studies on retinal photoreceptors in several crocodilian species, but there is only one behavioral study on actual color perception in a single individual (Nickel, 1960). From training procedures at zoological facilities, we know that crocodilians can discriminate colors (Stevenson, 2019), and in a functional magnetic resonance imaging (fMRI) study, Nile crocodiles (Crocodylus niloticus) showed differential responses to red and green stimuli (Behroozi et al., 2018). But it is still unknown what colors crocodilians can perceive and how accurately they distinguish them (see also the Anatomy of the Eye section).

COMPARATIVE COGNITION \& BEHAVIOR REVIEWS 
In this review, I address visual, acoustic, olfactory, gustatory, and tactile perception in crocodilians, and shortly I touch on the potential for magnetoreception. I briefly describe the anatomy and physiology of their sensory organs but thereby mainly focus on aspects that are special or unique to them. Subsequently, I provide a summary of the literature on behavioral studies associated with crocodilian perception.

\section{Visual Perception \\ Anatomy of the Eye}

The eyes of crocodilians have two eyelids and a translucent nictitating membrane. The latter shuts horizontally over the eye when the animal submerges (Grigg \& Kirshner, 2015). The eye has a basic vertebrate anatomy. A strongly curved cornea covers the iris and lens (Grigg \& Kirshner, 2015). Light passes through these

Figure 1. The nostrils, eyes, and ears of crocodilians can remain in air while most of their body is hidden under water; female American alligator (Alligators mississippiensis) at the Tom Yawkey Wildlife Center, South Carolina, USA (A). Integumentary sensory organs are small dome-shaped pressure receptors on crocodilian scales; male American alligator at the alligator research facility, Lund University, Sweden (B). Crocodilians can seal the pharyngeal cavity by pressing the palatal valve (pv), which is fused to the tongue (t), against the palatal fold (pf); female saltwater crocodile (Crocodylus porosus) at Crocodiles of the World, UK (C). Photos by the author.
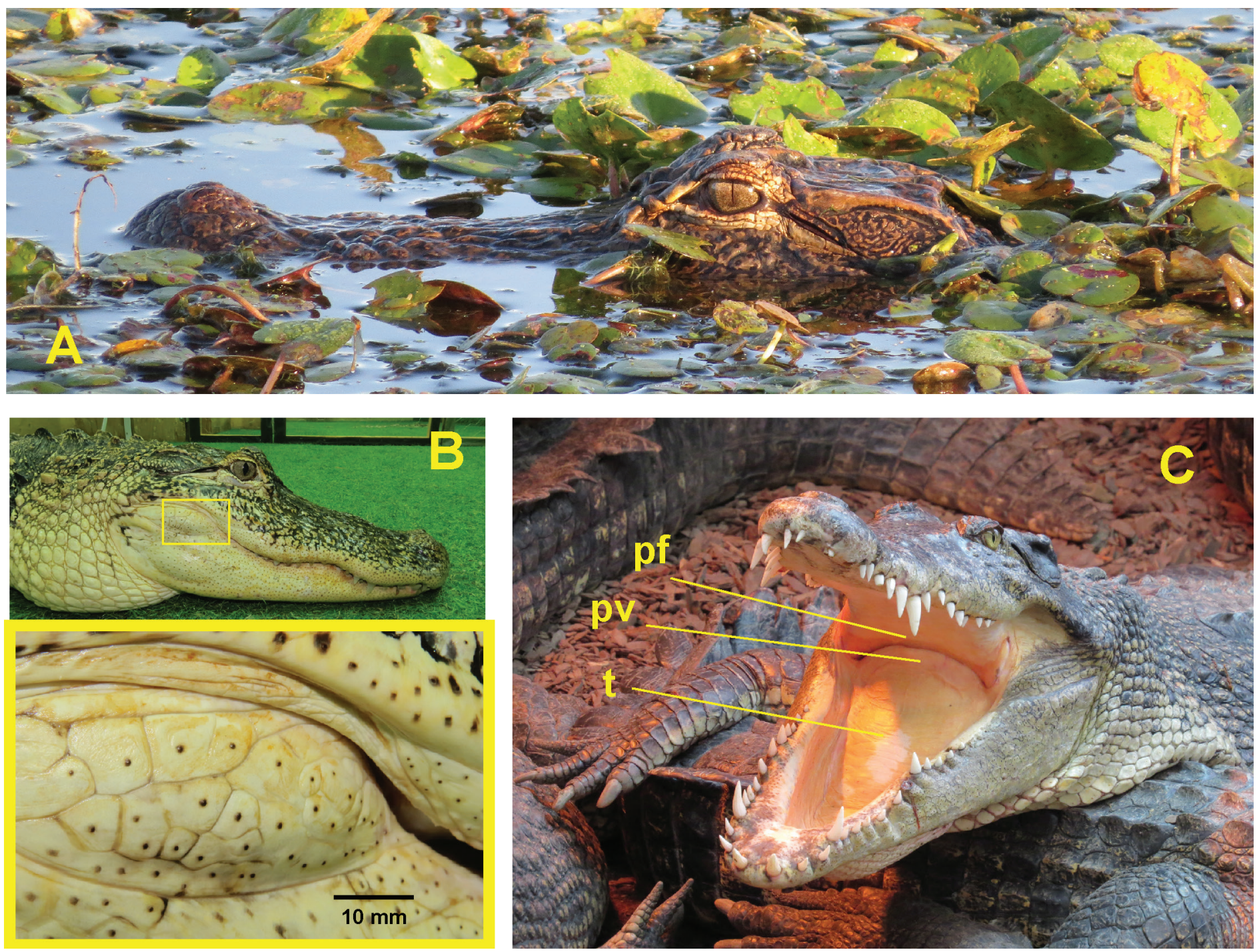
structures and the vitreous body to reach the retina. There it gets absorbed by the pigments of the photoreceptors, and the resulting electric signal travels via the ganglion cells and the optic nerve to the brain. A speciality of the crocodilian eye is the distribution of the retinal ganglion cells: It is most dense along a horizontal band running anterior-posteriorly through the retina (Laurens \& Detwiler, 1921; Nagloo, Collin, Hemmi, \& Hart, 2016). This band may make crocodilians sensitive to movements along the water surface and at the shore line without having to turn their head. The retina of all crocodilians investigated to date contains one type of rod, which is the most common photoreceptor type. Rod cells are the most sensitive photoreceptors under lowlight conditions, which indicates that the crocodilian retina evolved for improved vison at night. In American alligators (Alligator mississippiensis), an estimated $72 \%$ of the retina is composed of rods (Sillman, Ronan, \& Loew, 1991).

The other photoreceptors - the cones-enable color vision, as they are sensitive to light of different wave lengths depending on their pigment. The composition of cones is not uniform across crocodilians. The American alligator and the spectacled caiman (Caiman crocodilus), both members of the Alligatoridae, have two single cones and one double cone (Govardovskii, Chkheidze, \& Zueva, 1988; Sillman et al., 1991), whereas the freshwater crocodile (Crocodylus johnstoni) and the saltwater crocodile (Crocodylus porosus) have three single cones and one double cone (Nagloo et al., 2016). Double cones consist of a principal and an accessory cone, which can be sensitive to different wavelengths. It is suspected, yet not conclusively shown, that double cones contribute to color vision. Generally, an animal should have keener color vision if it has more cones absorbing at different wavelengths. Interestingly, both pigments of the double cone in the two crocodile species absorb at the same wavelength as one of their single cones. In the two members of the Alligatoridae, the double cone pigments absorb at two different wavelengths, which are also intermediate to their two single cones. Therefore, the two crocodiles are probably trichromatic. The two alligatorids are either dichromats or tetrachromats, depending on whether double cones are actually used for color vision (Nagloo et al., 2016). Overall, the crocodilian cones, studied to date, absorb light between 424 $\mathrm{nm}$ (violet) and $566 \mathrm{~nm}$ (yellow) in wavelength. There is no evidence that crocodilians could be sensitive to ultraviolet light (Nagloo et al., 2016). The anatomy of the modern crocodilian eye is a good example of the aforementioned intermediacy of this taxonomic order as model organisms. For instance, crocodilians lack scleral ossicles, which are found in many vertebrates other than mammals (Grigg \& Kirshner, 2015), and their cone cells do not contain oil droplets, which are present in most other reptilians including birds (Underwood, 1970). However, double cones are absent in eutherian mammals (Grigg \& Kirshner, 2015).

The field of vision in crocodilians is relatively large, probably up to 260 degrees (Grigg \& Kirshner, 2015; Underwood, 1970). The angles of the corneas suggest that there is a field of binocular vision starting approximately at the nostrils and opening up to a $25^{\circ}$ angle (Underwood, 1970). Histochemical tracing of the retinal connection between the brain and the eye in freshwater crocodiles revealed that crocodilians have the same neurological pathways as birds, which strongly suggests that they have well-developed binocular vision (Grigg \& Kirshner, 2015; Pettigrew \& Grigg, 1990). Behavioral studies on the visual field are lacking to date.

\section{Adapting to Different Light Conditions}

Most crocodilians live in equatorial regions with very bright sunlight, and they can be active by day and night. Hence, they deal with drastically varying light conditions. The crocodilian pupil is a vertical slit in intense light and becomes a round opening in dimmer surroundings (Grigg \& Kirshner, 2015). The retina cells are not static, the pigments can shift their location to cope with the current light conditions, and the rod cells expand in the absence of strong light (Grigg \& Kirshner, 2015; Laurens \& Detwiler, 1921). The pigment in the rods are made up of rhodopsin (Wald, Brown, \& Kennedy, 1957), which has vitamin A as a precursor and is particularly sensitive to light. Finally, crocodilians are the only nonavian reptiles to have a tapetum lucidum (Abelsdorff, 1898), a reflective layer directly behind the retina. Light passing through the retina is reflected back past the photoreceptors, which increases the chance for photons to interact with a pigment. As in nocturnal mammals and birds, the crocodilian tapetum lucidum hence acts a residual light amplifier.

\section{Seeing Underwater}

The crocodilian eye appears to lack specific adaptations for underwater vision. It was once suspected that the nictitating membrane could aid crocodilians to focus when submerged (Grigg \& Kirshner, 2015).

COMPARATIVE COGNITION \& BEHAVIOR REVIEWS 
However, using retinoscopy and photorefraction in several species, it has been demonstrated that crocodilians of all three families can focus well on distant targets in air but not underwater (Fleishman, Howland, Howland, Rand, \& Davenport, 1988). The nictitating skin's main function might be to keep water out of the eye and to focus quickly after surfacing. It certainly acts as protection against mechanical damage as well, yet crocodilians usually close their eyes entirely when grabbing prey or snapping at conspecifics during antagonistic interactions. There is a possibility that saltwater crocodiles adapted their photoreceptors to the marine environment by having a larger proportion of $\mathrm{A}_{1}$ than $\mathrm{A}_{2}$ pigments compared with freshwater crocodiles (Nagloo et al., 2016). However, only $\mathrm{A}_{1}$ pigments have been documented in Nile crocodiles, American alligators, and spectacled caimans, which are all living exclusively in freshwater habitats (Dartnall \& Lythgoe, 1965; Govardovskii et al., 1988; Sillman et al., 1991). So far, it is not clear what has led to these differences. Besides the intriguing histological questions, the extent of underwater vision in crocodilians is yet another aspect awaiting behavioral evaluation.

\section{Visual Communication}

Vision is not only important for catching prey. Crocodilians also have a variety of visual social signals, which can be subtle and require keen vision and attention. For instance, the "inflated" posture signals dominance (Garrick \& Lang, 1977). In water, it results in the postoccipitals (plates caudal to the skull) and most of the back being lifted disproportionally high over the surface. On land, a dominant animal performs a high-walk with its back arched, the mouth agape, and the tip of the snout pointing to the ground. Subordinate animals keep a low profile in water, and most of their body remains under the surface. When walking past or away from a dominant on land, a subordinate's mouth is closed and the head parallel to the floor. When stationary, a subordinate can appease a threatening dominant by raising its snout tip up and exposing the gular pouch while keeping the mouth closed (Garrick \& Lang, 1977). This submission sign is also performed by females toward males before mating. Crocodilians use visual signals in all aspects of their social behavior, and the repertoire appears to be universal across species. Visual communication in crocodilians still requires more documentation and empirical investigation.

\section{Acoustic Perception}

Crocodilians are the most vocal nonavian reptiles. All species are more vocally active in their first months than later in life. As adults, crocodile species of the genus Crocodylus call only rarely, whereas members of the Alligatoridae frequently produce vocal signals (Grigg \& Kirshner, 2015). Nevertheless, the crocodilian call repertoire seems to be universal (Britton, 2001) with species of different families responding appropriately to one another's calls (Vergne, Aubin, Martin, \& Mathevon, 2012). Research on vocal communication in crocodilians has so far mainly focused on motheroffspring interactions. The vocal behavior of adults, particularly perception, remains understudied.

\section{Physiology of the Ear}

The ears of crocodilians lie directly posterior to the eyes. Unlike in most nonavian reptiles, their ears are covered by muscular flaps and only a small slit is open when they are in air (Grigg \& Kirshner, 2015). The flaps seal shut when the animal submerges. Under each flap lies a relatively large, oval-shaped tympanic membrane. The middle and inner ear of crocodilians have an astonishing resemblance to the anatomic structures found in birds, particularly in palaeognaths (Gleich \& Manley, 2000). Therefore, it is highly likely that this hearing apparatus is ancestral for archosaurs and was present in extinct dinosaurs. Like all reptilians, including birds, the middle ear of crocodilians has only one auditory ossicle - the columella, which corresponds to the stapes in the mammalian lineage (Saunders, Duncan, Doan, $\&$ Werner, 2000). The columella is not completely ossified. The cartilaginous extracolumella connects the bony columellar shaft with the tympanum via the tympanic, stylohyal, and extrastapedial processes (Wever, 1978). The suprastapedial process, another part of the anchorage on the tympanum, is attached to the extracolumellar muscle. This muscle is found in crocodilians and mainly in vocally active lizards, such as geckos, and might be stimulated during call production to reduce the sensitivity of the tympanum to acoustic pressure (Saunders et al., 2000). The columellar shaft ends in a relatively large foot plate in comparison with other reptiles (Saunders et al., 2000). The inner ear has a shorter cochlear duct than most mammals and, as in birds, other reptiles, and monotremes, is not coiled "but bent and somewhat twisted" (Gleich \& Manley, 2000, p. 72). The hair cells lie on a basilar papilla (Vergne et al., 2009), similar to amphibians and all other reptiles. Crocodilians have 
two types of hair cells (Retzius, 1884) just as birds and mammals (Gleich \& Manley, 2000). But crocodilians have a less gradual transition from tall to short hair cells than birds (Baird, 1974). Both hair cell types are innervated afferently and efferently (von Düring, Karduck, \& Richter, 1974), whereas in birds, short hair cells are innervated only efferently (Fischer, 1994). Vergne and colleagues (2009) pointed out that the properties of the inner ear are suitable to trace the evolution of hearing in the reptilian lineage: Because palaeognaths have less variation in the length of their hair cells than more derived neognaths, such as songbirds (Köppl, Gleich, Schwabedissen, Siegl, \& Manley, 1998), and because nonarchosaurian reptiles also barely show a gradient in hair cell shapes (Manley \& Gleich, 1992), crocodilians probably independently evolved the stronger segregation of hair cell shape across the basilar papilla and birds lost the afferent innervation of their short hair cells after they split from the common ancestor of all Archosaurs. There are two structures connected to the inner ear of crocodilians, and their contribution to perception is not conclusive: the sacculus and the lagenar macula. The latter is discussed briefly in the section titled The Potential for Magnetoreception. The sacculus might be involved in perceiving low-frequency sounds including infrasound (Todd, 2007), which is part of the crocodilian long-distance call display (see the Adult Acoustic Communication section). However, there is no empirical evidence that crocodilians can hear frequencies below the human hearing range.

The knowledge on neurological pathways for the perception of sound in crocodilians has been reviewed by Vergne et al. (2009). They are hardly distinguishable from its counterpart in birds (Leake, 1974; Manley, 1970). In an fMRI study, the blood-oxygenation-leveldependent (BOLD) signal was recorded in the telencephalon of Nile crocodiles in response to acoustic stimuli (Behroozi et al., 2018). The signal increased on either side of the rostromedial and caudocentral anterior dorsal ventricular ridge (ADVR) when simple one-tone stimuli were played back. But when a complex stimulus was presented, an additional region was activated in the caudomedial ADVR. This observation of potentially higher-order processing of more complex acoustic patterns is very reminiscent of what has been documented in birds and mammals (Behroozi et al., 2018). Interestingly, the complex stimulus was a piece of music (Johann Sebastian Bach, an excerpt from the Brandenburg Concerto no. 4) previously used in an fMRI study on European starlings (Sturnus vulgaris; Van Meir et al.,
2005), and it caused responses in similar areas of the brain in both species. Therefore, it is possible that such a stimulus will result in the activation of comparable brain regions in all archosaurs. This mechanism is hence probably not linked to song learning and parallel capacities such as human speech as has previously been proposed (Van Meir et al., 2005). This finding again highlights the importance of crocodilians to understand the evolution of perception and cognition in the amniotes. For future fMRI studies, the focus should shift toward conspecific vocalizations and other biologically relevant stimuli.

\section{Sound Sensitivity and Localization}

The ear lids of crocodilians affect their hearing. In spectacled caimans, the cochlear microphonic sensitivity is on average $15 \mathrm{~dB}$ higher when the lids are open than when they are closed for frequencies between 100 $\mathrm{Hz}$ and $3 \mathrm{kHz}$ (Wever \& Vernon, 1957). Like all reptiles, crocodilians are less sensitive to high frequencies than most mammals, as they lack the lever system with three ossicles, which makes the mammalian middle ear more efficient at transmitting fast vibrations of the tympanum to the labyrinth. Higgs and colleagues (2002) measured the auditory brain stem responses to sound in juvenile American alligators in air and underwater, and they compared the results to measurements obtained from budgerigar and goldfish. Their findings were in agreement with an older study measuring cochlear potential in American alligators, American crocodiles (Crocodylus acutus), and spectacled caiman (Wever \& Vernon, 1957). In air, the audiogram of alligator and budgerigar show a similar curve, yet it is slightly shifted with the avian ear being more sensitive to higher frequencies. In alligators, responses were measurable between 0.1 and $8.0 \mathrm{kHz}$. The amplitude threshold was lowest around $0.8-1.5 \mathrm{kHz}$, which is the same space occupied by the dominant frequency bands of crocodilian hatchling calls (Britton, 2001). In water, the hearing sensitivity of alligators is overall stronger than in goldfish yet covers a smaller frequency range. When crocodilians dive, an air bubble usually gets caught under the ear lid over the tympanum. Its removal has no measurable effect on the auditory brain stem response, which suggests that, underwater, sound is not perceived via the tympanum but probably by bone conduction (Higgs et al., 2002).

Many observations in the wild and captivity strongly suggest that crocodilians are highly capable of localizing sound, yet conclusive experimental support was only recently provided by a laboratory study of phonotaxis in juvenile American alligators (Bierman \& Carr, 2015).

COMPARATIVE COGNITION \& BEHAVIOR REVIEWS 
Crocodilians seem to possess an array of adaptations for directional hearing (for a review, see Bierman \& Carr, 2015). In larger, more mature specimens, the external head morphology contributes to the localization of sounds above $1.5 \mathrm{kHz}$ (Papet, Grimault, Boyer, \& Mathevon, 2019). As in many vertebrates other than mammals, the middle ear cavities of crocodilians are coupled (Carr, Christensen-Dalsgaard, \& Bierman, 2016) forming a pressure difference receiver system (Bierman et al., 2014). In contrast to lizards, their cavities are connected not via the pharynx but by paratympanic sinuses. The connections are running below and above the brain case (Witmer, Ridgely, Dufeau, \& Semones, 2008). These channels are not blocked by any membranes (Bierman et al., 2014). Like in birds, they increase the time delay between the two eardrums (Carr, Soares, Smolders, \& Simon, 2009) and hence result in a better directional perception for lower sounds with longer wave lengths. The crocodilian tympana are sensitive to localization cues, and the auditory brain stem response itself is mildly directional (Bierman et al., 2014).

In summary, the auditory sensitivity of crocodilians is similar to birds, and they possess several adaptions to localize sound cues while lying on land or moving at the air-water interface (Papet et al., 2019).

\section{Communication During Hatching}

Crocodilians build mound nests or excavate holes in sandy soil in which to lay their eggs. They hatch after 60-115 days (Stevenson, 2019). In the final phase of incubation, up to 5 days before hatching, the young start to call from inside the egg (Somaweera \& Shine, 2012). These "prehatching calls" are perceived by the siblings in the other eggs, and they also start to vocalize. The chorus of these calls stimulates and synchronizes the hatching of the clutch (Vergne \& Mathevon, 2008). In Nile crocodiles, a playback experiment showed that specifically prehatching calls had this effect, but a random noise of the same amplitude did not (Vergne \& Mathevon, 2008). The calls can also be heard by the nest-guarding parent and animate it to excavate the hatchlings. Nile crocodile females were shown to dig for a loudspeaker playing prehatching calls hidden in substrate (Vergne \& Mathevon, 2008). After leaving the egg, hatchlings continue to call to attract the parent. Crocodilian females, or the males in rarer cases (Lang, Whitaker, \& Andrews, 1986), carry hatchlings and yet-unhatched eggs in their mouths to the water. They then crack the eggs open to release the last hatchlings. The parents carry only fertile eggs and ignore or even swallow infertile ones (Somaweera \& Shine, 2012). Parents may perform this discrimination solely by perceiving prehatching calls (Reber, 2018). The vocalizations produced right after hatching are acoustically distinct. They are shorter in duration and higher in sound energy and peak frequency (Britton, 2001). It is probable that the egg shell dampens the calls (Vergne et al., 2009) and that these differences neither are perceived by conspecifics nor serve a specific function. The "posthatching" calls of Nile crocodiles also do not carry cues to a caller's individual identity (Vergne, Avril, Martin, \& Mathevon, 2007).

\section{Early Life Vocal Signals}

Hatchlings of all crocodilian species frequently utter "contact calls" - high-pitched chirps with a low amplitude (Vergne et al., 2012). In older literature they were also denoted as "grunts" or "barks" (Campbell, 1973; Herzog \& Burghardt, 1977). Contact calls are stereotyped, and hatchlings may produce them spontaneously several times per minute. They probably serve group cohesion, because hatchlings call when approaching and when being approached by other members of their pod while foraging as a group (Campbell, 1973; Herzog \& Burghardt, 1977). Upon hearing recordings of contact calls of same-aged conspecifics, young black caimans (Melanosuchus niger) gradually swim in the general direction of the loudspeaker (Vergne, Aubin, Taylor, \& Mathevon, 2011). The prandial (feeding) state of young crocodilians appears to affect their response to contact calls, which further supports the contextual connection to foraging: In the presence of a food odor, juvenile Nile crocodiles spend more time orienting toward playbacks of contact calls compared with a noise stimulus only if they have not eaten in 2 days; sated juveniles do not show this discrimination but are more likely to explore their surroundings independent of playback type (Chabrolles, Coureaud, Boyer, Mathevon, \& Beauchaud, 2017). Adult crocodilians attend to hatchling and juvenile contact calls (Vergne et al., 2012) and can probably perceive the body size of the producers. A blind American alligator female was observed to grab and evict a yearling juvenile from the vicinity of her new pod of hatchlings, presumably judging its size or age by its calls alone (Hunt \& Watanabe, 1982). Contact calls and their perception are highly conserved across all recent crocodilians. Nile crocodiles respond equally to recordings of contact calls produced by conspecifics, spectacled caimans, and black caimans (Vergne et al., 2012). Evidently, the acoustic parameter defining a crocodilian contact call is the 
downward sweeping modulation of the fundamental frequency. Digitally synthesized contact calls containing only the first harmonic and lacking amplitude modulation promote the same responses in juvenile Nile crocodiles and spectacled caimans as natural call recordings (Vergne et al., 2012). Given the phylogenetic position of crocodiles and caimans, contact calls and their perception are possibly ancestral for the entire Crocodylia.

The "distress call" of young crocodilians is essentially a louder version of the contact call with a higher starting frequency and a steeper frequency modulation (Britton, 2001). The two vocalizations grade into each other but are perceived as contextually distinct call types (Vergne et al., 2011). Juvenile crocodilians threatened by a predator produce several distress calls in quick succession, which alerts the guarding parent and elicits protection. When distress calls were played back to a pod of young black caiman with their mother, the juveniles stopped moving and started to distress call themselves while the adult female rapidly approached the loudspeaker (Vergne et al., 2011). In at least five crocodilian species, the fundamental frequency of distress calls decreases gradually with increasing body size (Chabert et al., 2015). This change affects the responses of protecting parents. Wild nest-guarding Nile crocodile females show more approaches to distress calls of small than of large juveniles (Chabert et al., 2015). Younger juveniles are more susceptible to predation and therefore require heightened attention by the parent.

\section{Adult Acoustic Communication}

All crocodilian species vocalize as adults. Although the acoustic properties of some calls have been studied, their function to date is purely inferred by observations (Vergne et al., 2009). For instance, hissing appears to be a threat signal, as it is usually followed by biting attempts and receivers become alert and often retreat (Britton, 2001). A further, lesser known example is the "burp-trill" - a low-frequency rumble produced by female American alligators guarding a pod (Hunt \& Watanabe, 1982; Joanen \& McNease, 1970), which seems to be directed at offspring and results in the hatchlings approaching their mother. Here, I discuss only the longdistance call displays in more detail, as they are probably multimodal in production and perception and provide an intriguing field for future studies.

The long-distance calls of adult crocodilians are commonly referred to as "bellows" in the Alligatoridae and "roars" in the Crocodylidae (Grigg \& Kirshner, 2015). They are the central event of a an elaborate advertisement display performed by either sex (Garrick \& Lang, 1977; Garrick, Lang, \& Herzog, 1978). They have been studied in most detail in alligators (Garrick, 1975; Vliet, 2001). American alligators bellow preferably in shallow waters. Before the actual bellow, they assume the "head oblique, tail arched" (HOTA) position, meaning they lift their head and tail out of the water (Garrick \& Lang, 1977). The animal audibly inhales and simultaneously raises the head higher, thereby exposing the

Figure 2. American alligators (Alligator mississippiensis) produce long-distance call displays including subaudible vibrations, visible by the "water dance" in males (A, Saint Augustine Alligator Farm Zoological Park, Florida, USA), followed by loud bellows (B), which carry cues to body size in their resonances (window length [s]: 0.1; dynamic range [rel dB]: 40.0). Photo by the author.
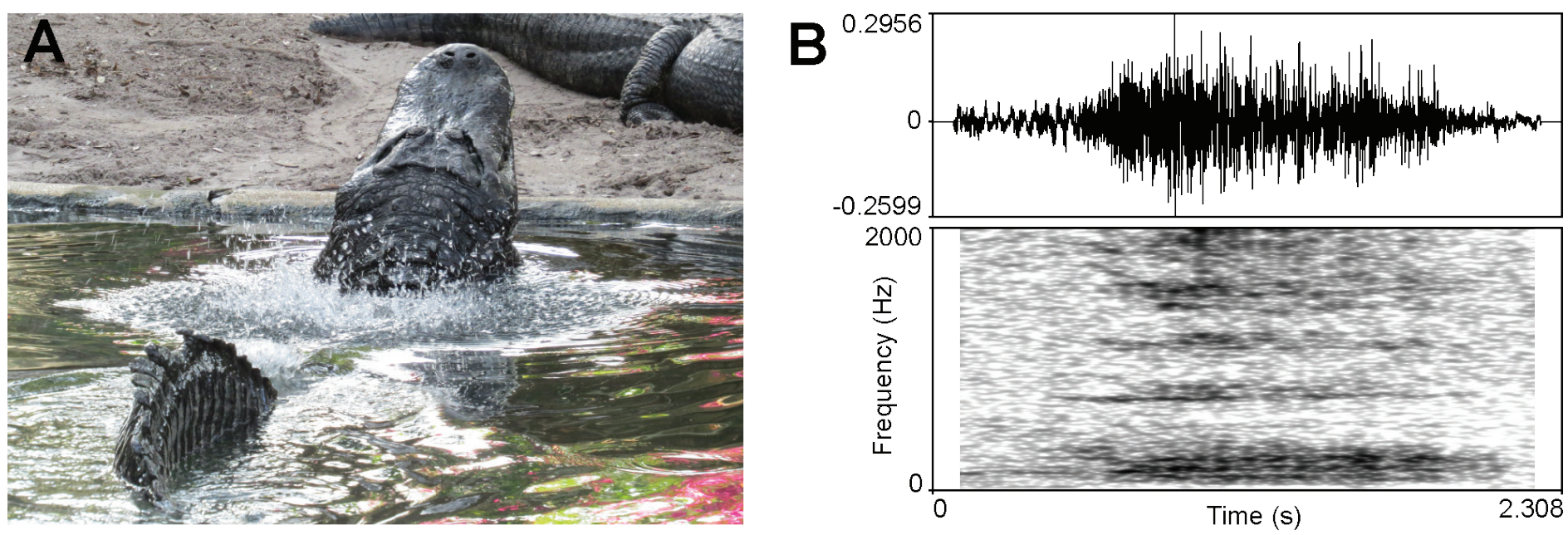

COMPARATIVE COGNITION \& BEHAVIOR REVIEWS 
neck and back. Then the alligator sinks into the water until only the head and tail remain above the surface. At this point in the display, males produce the so-called water dance, using infrasonic sound waves. These subaudible vibrations cause droplets of water to spray upward above the back and along the flanks (Figure 2A). Females either do not produce infrasound or do so to a much weaker extant, as their display lacks a water dance. Right afterward, the alligator bellows (Figure 2B). The call is a loud, low-pitched, pulsating rumble (Vliet, 1989). The function of the bellowing display is not fully understood. It is produced year-round, with the highest occurrence during the mating season, and strongly resembles mating displays of some mammals, such as red deer or koalas. In those species, the resonance frequencies (formants) of the vocal tract advertise a caller's body size, with lower frequencies indicating larger animals (Charlton, Ellis, Brumm, Nilsson, \& Fitch, 2012; Charlton, Reby, \& McComb, 2007). The bellows of alligators contain formants (Reber, Nishimura, Janisch, Robertson, \& Fitch, 2015), and they are strongly negatively correlated with body size (Reber et al., 2017). It is unknown whether alligators can perceive the cues to size in bellows and what else they can deduce from them. Bellows are contagious in both American and Chinese alligators (Alligator sinsnesis; Joanen \& McNease, 1970; Wang et al., 2009), making a role in mate attraction and rival intimidation likely. Perception of bellowing might not only be auditory. The infrasonic "water dance" component makes the display sexually distinct, but there is no evidence that crocodilians can hear infrasound. They might actually feel the vibrations in water via their integumentary sensory organs (see the Tactile Perception section). Because there are also reports of scent glands being active during bellowing (Vliet, 1989), this display might stimulate almost all sensory modalities discussed in this article.

\section{Olfaction and Gustation}

\section{The Physiology of Olfaction and Gustation}

The most striking difference between an avian brain and a crocodilian brain is the latter's massive olfactory bulb (Vergne et al., 2009). However, just like birds, crocodilians lack a Jacobson's organ (vomeronasal organ), which represents an important difference to other nonavian reptiles. The Jacobson's organ rudimentarily develops during embryogenesis but is no longer present at the time of hatching (Parsons, 1970).
The oblong crocodilian skull supports a complex system of cavities and recesses, which play important roles in respiration and olfaction. During inhalation, air enters a vestibulum through the nostrils and flows through the nasal cavity past three main projections (nasal conchae), past a system of sinuses, and into the nasopharyngeal duct. From there, the air proceeds through the choanae (internal nares) into the pharyngeal cavity and into the trachea. The many projections in the crocodilian skull massively enhance the surface area covered by epithelium (Grigg \& Kirshner, 2015). The dorsal and the dorsomedial sections of the main nasal cavity are lined with the olfactory epithelium, which does not seem to extend into the sinuses, at least not in the Nile crocodile or the spectacled caiman (Saint Girons, 1976). In these two species, it was further reported that all projections and the ventral side of the nasal cavity are covered in non-sensory respiratory epithelium (Saint Girons, 1976). A newer study on American alligators found that the nasal cavity is almost entirely lined with olfactory epithelium and that only a few ventral sections contained none (Hansen, 2007). To date, it cannot be said with certainty whether these findings differ because of the histological methodologies employed or the species studied. Hansen (2007) also discovered that the olfactory epithelium of American alligators contains not only olfactory receptor neurons but also solitary chemosensory cells. The latter cells have no axon, are innervated by the trigeminal nerve, and appear to represent an evolutionarily conserved trait in the vertebrata, as they can be found in mammals, amphibians, teleost fish, elasmobranchs, and hagfish (Hansen, 2007). The receptor neurons of olfactory epithelium of crocodilians are connected to the olfactory bulb via the olfactory nerves (Weldon \& Ferguson, 1993). Crocodilians also have taste buds on their tongue, the palatal valve and fold, and the walls of the pharyngeal cavity (Bath, 1906; Ferguson, 1981; Weldon \& Ferguson, 1993).

\section{Behaviors Associated With Chemoreception}

Out of water, crocodilians can frequently be observed to rhythmically raise and lower the floor of their lower jaw (pharynx) while having the head lifted slightly off the ground. This behavior, referred to as "gular pumping," is the main form of respiration in all amphibians and all nonarchosaurian reptiles. These animals have to gulp air down into their lungs, as they do not possess a diaphragm to extend the lungs during inhalation. Crocodilians are the only taxon to possess a so-called pseudodiaphragm, 
a sheet of connective tissue separating the pleural cavity containing the lungs from the rest of the thorax (Borrichius, 1674; Claessens, 2009). The lungs are extended and filled by a contraction of the paired diaphragmaticus muscles, which pull the liver and other organs toward the pelvis (Gans \& Clark, 1976). Hence, crocodilians do not require gular pumping for respiration. The palatal valve is closed during this motion, and the pharyngeal cavity is rhythmically compressed and extended, which pushes air up and down the nasal cavity and past the olfactory epithelium (Pooley \& Gans, 1976). Gular pumping and a sniffing motion of the nares coincide with heightened neural activity (measurable by electroencephalography) in the olfactory bulb (Huggins, Parsons, \& Pena, 1968), confirming that crocodilians are the only nonavian reptiles using gular pumping primarily for olfaction. The rate of gular pumping can be used to assess olfactory perception. Juvenile American alligators display more gular pumping to beef smell than to a control with distilled water (Weldon, Swenson, Olson, \& Brinkmeier, 1990). They also behaviorally discriminate between some scents indicating familiar prey items. For instance, the smell of nutria promotes more gular pumping than olfactory cues to catfish (Weldon, Brinkmeier, \& Fortunato, 1992).

When a food item is dropped into water close to a crocodilian's head, the animal often submerges, opens its mouth, and moves its head in a waving motion from side to side. It is possible that the animal is gropingly searching for the food. But a study suggests that this behavior helps detecting waterborne chemical cues: American alligators showed a higher frequency of underwater head waves when exposed to beef extract than to pure water (Weldon et al., 1990). Whether the subjects used olfaction or gustation is not clear, but because crocodilians open their mouths under water during these head waves, it is at least plausible that they use the taste buds on their tongue to search for food. Crocodilians do not perform gular pumping with their heads beneath the water surface (Weldon \& Ferguson, 1993).

Crocodilians do eat carrion but prefer fresh prey. For example, Nile crocodiles choose fresh over defrosted fish (Morpurgo, Gvaryahu, \& Robinzon, 1991). Edibility of prey appears to be mainly assessed by gustation, as crocodilians take chemically protected prey in their mouths but subsequently discard it. American alligators bite into yellow-spotted salamanders but do not swallow them (Barach, 1951). They equally refuse to eat chicken pieces coated with scent gland secretions of western diamondback rattlesnakes and bull snakes (Weldon \& McNease, 1991) but only after taking them into their mouths. The same species also shows a tendency for more gular pumps to decomposing than to fresh meat, which suggests that the rate of gular pumping does not reflect food preference (Weldon \& Ferguson, 1993).

\section{Chemical Communication}

Crocodilians are very likely to have extensive chemical intraspecific communication, which, on the behavioral side, is critically understudied. They produce secretions from three main types of skin glands: mandibular glands, paracloacal glands, and dorsal integumentary glands.

The two mandibular glands are found at either side of the posterior sections of lower jaw arcs. In appearance, they resemble two small black brushes, which are hidden inside a fold of skin but are exposed in various contexts linked to arousal. Based on observations in Nile crocodiles (Kofron, 1991) and American alligators (Vliet, 2001), the mandibular glands appear to be frequently used in courtship: Both males and females evert the glands when rubbing their heads over each other, probably excreting pheromones.

The paracloacal glands lie in the ectodermal walls (proctodaeum) under the cloaca. Just as the mandibular glands, they secrete a large variety of chemicals in different compositions (Weldon \& Wheeler, 2001), some of which are rare and uncommon (Krückert, Flachsbarth, Schulz, Hentschel, \& Weldon, 2006). For instance, the aromatic ketone dianeackerone has not been found anywhere else in the natural world other than in the paracloacal glands of the West African dwarf crocodile (Osteolaemus tetraspis; Whyte et al., 1999). The secretions of the paracloacal glands are thought to play a role in territorial defence (Grigg \& Kirshner, 2015). They can be observed by smell and visually as a musky oily film floating at the water surface-for example, after the "head slaps" of an American alligator (Vliet, 1989), a behavior often shown in agonistic interactions (Garrick \& Lang, 1977).

The final group - the dorsal integumentary glandshave been studied the least to date. They have been found in both alligator and several crocodile species, suggesting that they are present in all crocodilians (Grigg \& Kirshner, 2015; Reese, 1921; Richardson \& Park, 2001). Dorsal integumentary glands appear to be most active in ovo until a few years posthatching. They might not be secreting later in life (Grigg \& Kirshner, 2015) or have a sensory function (Cannon, Davis, \& Weldon, 1996). But it is possible that the secretions play a role in hatchling pod cohesion and/or mother-offspring interactions (Richardson \& Park, 2001).

COMPARATIVE COGNITION \& BEHAVIOR REVIEWS 
Despite this apparent richness in opportunities for experiments, there is only one study on olfactory communication in crocodilians: Juvenile American alligators display more gular pumps to the scents of secretions of the gular glands and the paracloacal glands (methylene chloride extract) than to a control (pure methylene chloride; Weldon \& Ferguson, 1993). Both secretion samples were a mixture from the glands of several adult alligators, males and females. There was no significant difference in responsiveness to secretions from the gular glands and the paracloacal glands (Weldon \& Ferguson, 1993).

\section{Chemosensory Imprinting}

Newly hatched crocodilians can quickly develop food preferences, which can differ between clutches within the same holding facility (Webb, Manolis, \& Cooper-Preston, 1990). Although small live prey is immediately pursued by hatchlings, recognition of other food sources has to be learned (Morpurgo et al., 1991).

Crocodilians are already responsive to chemosensory cues in ovo. In a detailed study (Sneddon, Hepper, \& Manolis, 2000), eggs of saltwater crocodiles were treated with strawberry essence (commercially available food flavoring) or water, or they received no treatment. The essence and water were applied daily for 24 days in the final stages of incubation, and eggs were then thoroughly cleaned before hatching. Subsequently, the hatchlings were fed from two trays in their holding pen, one with plain and one with strawberry-flavored food. Hatchlings, which had been exposed to strawberry essence in ovo, showed a significant preference for the strawberryflavored food compared with subjects that had received either none or the water treatment. This preference was not found if the animals were given the choice between plain food and food treated with an equivalent orange fruit essence. This study was the first evidence of prenatal learning in nonavian reptiles and demonstrates the relevance of chemosensory perception in crocodilians.

\section{Localizing Food via Chemoreception}

Several reports indicate that crocodilians found food sources far from the water's edge and presumably by olfaction alone. Mugger crocodiles (Crocodylus palustris) were seen feeding on tiger kills $450 \mathrm{~m}$ from the closest water source in India (Brander, 1923). Similarly, Nile crocodiles were observed at an elephant carcass $700 \mathrm{~m}$ inland (Cott, 1961). But whether crocodilians can actually locate food by smell has received little experimental evaluation. Under laboratory conditions, juvenile Nile crocodiles stayed closer to an olfactory meat stimulus compared with a water control if they had not eaten in 2 days (Chabrolles et al., 2017). In a two-choice task, captive adult American alligators were presented with two paper bags - one containing meat, the other more paper (Scott \& Weldon, 1990). The bags were hung into the water area of the enclosure, with $6.8 \mathrm{~m}$ distance between them. Depending on condition, the test bag contained beef, nutria, snake, or nutria extract. The alligators removed the meat bags more often from the ropes than they did the controls. There was no difference in latency to approach the bags, but subjects more often touched the bags with meat first. On 30 occasions the alligators grabbed the control bag and then let it go without removing it; this happened only 11 times with test bags. This action suggests that the animals used olfaction and gustation to find the bag with meat and that even with a decent distance between stimuli, locating food by smell was challenging. Crocodilians probably excel at finding food via olfaction over large distances, but they might struggle to peruse a specific smell up close within a smaller area. The external nares of crocodilians lie exceptionally close together given their large skull size, suggesting that they are not using tropotaxis (orientation by comparing intensity of perception of the same stimulus between the two nares) to find a food source (Stoddart, 1979).

\section{Tactile Perception}

\section{The Integumentary Sensory Organs}

The dated German term for crocodilian is Panzerechse, which literally means "armoured lizard." The epidermis of crocodilians is indeed firm and, in several sections, directly covers bony plates (osteoderms). Nevertheless, crocodilians are responsive to touch and water vibrations (Grigg \& Kirshner, 2015). All crocodilians have numerous small dome-shaped pressure receptors on their skin, the so-called integumentary sensory organs (Brazaitis, 1987). At close inspection they are visible as black dots on the scales (Figure 1B). Integumentary sensory organs are elevations of the epidermis on which the striatum corneum is thinner (Jackson, Butler, \& Youson, 1996; von Düring, 1974) and includes many free nerve endings and discoid receptors (Leitch \& Catania, 2012). In the dermis directly under the center of these little domes lies a complex of Merkel cells and a rich network of nerve endings (Leitch \& Catania, 2012). A detailed study using electrophysiological recordings of the ganglion of the trigeminal nerve, which is very 
prominent in crocodilians, demonstrated that integumentary sensory organs are indeed highly sensitive to touch (Leitch \& Catania, 2012). The same study also coined the often-cited statement that the mechanical sensitivity of integumentary sensory organs exceeds "that of primate fingertips."

Interestingly, all crocodiles, the Indian gharial (Gavialis gangeticus), and Malaysian gharial (Tomistoma schlegelii) have integumentary sensory organs on every section of the body, whereas in the Alligatoridae they occur only around the jaws and on the head scales (Grigg \& Kirshner, 2015; Leitch \& Catania, 2012). All species have the highest number of integumentary sensory organs around the jawline and generally the side of the head, with up to eight individual organs on the same scale (Grigg \& Kirshner, 2015). In contrast to the other senses discussed in this article, integumentary sensory organs are unique to crocodilians and appear to represent an adaptation to the semiaquatic life history. The body section most frequently exposed to air is the top of the cranial plate, which hardly possesses any integumentary sensory organs in all species (Grigg \& Kirshner, 2015). Further, extinct members of the Crocodylia, which had a terrestrial life history, did not have integumentary sensory organs (Soares, 2002).

\section{Evidence for Mechanoreception}

Besides their rather obvious role in mechanoreception, several diverse functions were proposed for integumentary sensory organs, including perception of salinity, $\mathrm{pH}$, and temperature (Grigg \& Kirshner, 2015). Electrophysiological analyses on fixated embryonic specimens of Nile crocodiles and spectacled caimans confirmed that integumentary sensory organs in both lineages are indeed sensitive to changes in $\mathrm{pH}$ and temperature but not to salinity (Di-Poï \& Milinkovitch, 2013). To the best of my knowledge, behavioral evidence for the perceptual capacities of integumentary sensory organs exist only for mechanoreception. American alligators oriented into the direction of water drippling into their tank in total darkness, but only if their jawline was at the surface, not if they were submerged (Soares, 2002). They also did not respond if their heads were out of the water; because Aligatoridae have no integumentary sensory organs on post-cranial sections of their body, this strongly suggests that these organs are needed to sense water movements. Similar experiments were later conducted with more American alligators and Nile crocodiles, where white noise was played back to mask any possible acoustic cues of food pellets hitting the water in darkened tanks (Leitch \& Catania, 2012). In this study, crocodiles also oriented toward free-swimming fish, even if they passed through behind them. In yet another study, Nile crocodiles were highly sensitive to surface movements and responded to ripples with frequencies of $15-80 \mathrm{~Hz}$ produced by blowing air onto water (Grap, Monzel, Kohl, \& Bleckmann, 2015).

Electrophysiological measurements strongly suggest that integumentary sensory organs are sensitive to infrasound (Leitch \& Catania, 2012), and it has been suggested that these organs, not the ears, perceive this aspect of crocodilian communication (Brazaitis \& Watanabe, 2011; Vergne et al., 2009). It appears that all crocodilians produce subaudible vibrations (Grigg \& Kirshner, 2015; J. Lang, personal communication; October 5, 2019). But, as previously mentioned, the Alligatoridae are more vocal than other crocodilians and possess integumentary sensory organs only on their head. Potentially, the reduced vocal activity of crocodiles and gharials could be linked to an increased ability to perceive subaudible vibrations via postcranial integumentary sensory organs.

Last, integumentary sensory organs also play a role in affiliative interactions. During courtship, mates rub against each other, and the jaws are targeted particularly. As the highest density of integumentary sensory organs is along the jawline, this behavior most likely serves to stimulate the nerve endings of the partner (Vliet, 2001).

\section{The Potential for Magnetoreception}

The lagenar macula is part of the inner ear of all vertebrates except the therian mammals (Gleich \& Manley, 2000). Besides its importance for balance, the lagenar macula has been hypothesized to allow crocodilians to sense the earth's magnetic field for long-distance orientation (Grigg \& Kirshner, 2015). Crocodilians can home over large distances (Read, Grigg, Irwin, Shanahan, \& Franklin, 2007), but a detailed investigation of a potential magnetic sensitivity has not been conducted to date. However, there is strong support for this hypothesis from a report on conservation efforts in Mexico (Dominguez-Laso, 2007). Spectacled caimans, American crocodiles, and Morelet's crocodiles (Crocodylus moreletii) are routinely captured and relocated if they are found close to human settlements. When a magnet was taped to the animals' ears or cranial plate after capture and removed before release, none of them managed to return to the capture location (at least for 4 years). Interestingly, crocodilians that received this magnet treatment moved their head in several directions after release.

COMPARATIVE COGNITION \& BEHAVIOR REVIEWS 
This behavior might be an orientation attempt using the lagenar macula, because untreated animals did not show such movements. Unfortunately, this report had no real control group (e.g., animals with nonmagnetic material taped to their ears) or coordinated releases at standardized distances. Future studies could take advantage of other relocation efforts (e.g., saltwater crocodiles in Australia) to clarify whether crocodilians are indeed sensitive to the earth's magnetic field.

\section{Conclusion and Future Direction}

The sensory organs of crocodilians have evolved to cope with challenges imposed by their semiaquatic life history and share traits with many other vertebrate taxa. Their anatomy and physiology are well understood. Future research should focus on behavioral studies to clarify what crocodilians can actually perceive. The discovery of both abilities and limitations in their perceptual capacities would be equally rewarding for comparative research. For instance, if crocodilians could not perceive body size cues in the long-distance calls of conspecifics, even though mammals and birds can do so, we could assume that this capacity might have evolved independently in the mammalian and avian lineages. Similarly, additional areas of perception could be explored in captive crocodilians by adapting setups previously used in other species. For example, social learning by visual observation has been investigated in mammals, birds, and more distantly related reptiles (Kis et al., 2015; Wilkinson et al., 2010). Should crocodilians possess equivalent capacities as these species, this would be a strong indication that social learning is and was universally present in amniotes. Previous setups will, of course, require modification to account for the physical strength and limitations in locomotion of crocodilians. However, they are clearly trainable and capable to manipulate objects in their environment (Stevenson, 2019). Future research will reveal how crocodilians perform in classic tasks of comparative cognition and, in turn, how diverse capacities evolved in birds and mammals. We have only just begun to exploit the potential of this intermediate model organism. In this review, I only briefly touched on another aspect of this research topic: Crocodilians and birds are the last living archosaurs and share a common ancestor with all dinosaurs. Traits consistently present in both extant lineages probably already existed in extinct dinosaurs. By studying crocodilians and comparing our findings with birds, we can learn more about these fascinating long-gone creatures.

\section{References}

Abelsdorff, G. (1898). Physiological observations on the eye of crocodiles. Archiv Für Physiologie, 155-167.

Baird, I. L., Keidel, W. D., \& Neff, W. D. (1974). Anatomical features of the inner ear in submammalian vertebrates. In Handbook of sensory physiology Vol. 5 (pp. 159-212). Berlin, Germany: Springer-Verlag. doi:10.1007/978-3-642-65829-7_6

Barach, J. P. (1951). The value of the skin secretions of the spotted salamander. Herpetologica, 7(2), 58. Retrieved from http://www.jstor.org/stable/27669655

Bath, W. (1906). Die Geschmacksorgane der Vögel und Krokodile. Berlin, Germany: Friedländer. Retrieved from https://catalog.hathitrust.org/Record/009229601

Behroozi, M., Billings, B. K., Helluy, X., Manger, P. R., Güntürkün, O., \& Ströckens, F. (2018). Functional MRI in the Nile crocodile: A new avenue for evolutionary neurobiology. Proceedings of the Royal Society B: Biological Sciences, 285(1877), 20180178. doi:10.1098/rspb.2018.0178

Bierman, H. S., \& Carr, C. E. (2015). Sound localization in the alligator. Hearing Research, 329, 11-20. doi:10.1016/j.heares.2015.05.009

Bierman, H. S., Thornton, J. L., Jones, H. G., Koka, K., Young, B. A., Brandt, C., ... Tollin, D. J. (2014). Biophysics of directional hearing in the American alligator (Alligator mississippiensis). The Journal of Experimental Biology, 217(7), 1094-1107. doi:10.1242/jeb.092866

Borrichius, O. (1674). Hermetis, Aegyptiorum, et chemicorum sapientia ab Hermanni Conringii animadversionibus. Hafniae.

Brander, A. A. D. (1923). Wild animals in Central India. London, England: E. Arnold \& Company. Retrieved from https://books.google.se/books?id $=$ CQYYAAAAIAAJ 
Brazaitis, P. (1987). Identification of crocodilian skins and products. In G. J. Webb, S. C. Manolis, \& P. J. Whitehead (Eds.), Wildlife management: Crocodiles and alligators (pp. 373-386). Sydney, Australia: Surrey Beatty \& Sons.

Brazaitis, P., \& Watanabe, M. E. (2011). Crocodilian behaviour: A window to dinosaur behaviour? Historical Biology, 23(1), 73-90. doi:10.1080/08912963.2011.560723

Britton, A. R. C., Grigg, G. C., Seebacher, F., \& Franklin, C. E. (2001). Review and classification of call types of juvenile crocodilians and factors affecting distress calls. In Crocodilian biology and evolution (pp. 364-377). Chipping Norton, Australia: Surrey Beatty \& Sons.

Campbell, H. W. (1973). Observations on the acoustic behavior of crocodilians. Zoologica, 58, 1-11.

Cannon, M. S., Davis, R. W., \& Weldon, P. J. (1996). Dorsal glands of Alligator mississippiensis: a histological and histochemical study. Journal of Zoology, 239(4), 625-631. doi:10.1111/j.1469-7998.1996.tb05466.x

Carr, C. E., Christensen-Dalsgaard, J., \& Bierman, H. (2016). Coupled ears in lizards and crocodilians. Biological Cybernetics, 110(4), 291-302. doi:10.1007/s00422-016-0698-2

Carr, C. E., Soares, D., Smolders, J., \& Simon, J. Z. (2009). Detection of interaural time differences in the alligator. The Journal of Neuroscience, 29(25), 7978-7990. doi:10.1523/JNEUROSCI.6154-08.2009

Chabert, T., Colin, A., Aubin, T., Shacks, V., Bourquin, S. L., Elsey, R. M., ... Mathevon, N. (2015). Size does matter: Crocodile mothers react more to the voice of smaller offspring. Scientific Reports, 5, Article 15547. doi:10.1038/srep15547

Chabrolles, L., Coureaud, G., Boyer, N., Mathevon, N., \& Beauchaud, M. (2017). Cross-sensory modulation in a future top predator, the young Nile crocodile. Royal Society Open Science, 4(6), Article 170386. doi:10.1098/rsos. 170386
Charlton, B. D., Ellis, W. A. H., Brumm, J., Nilsson, K., \& Fitch, W. T. (2012). Female koalas prefer bellows in which lower formants indicate larger males. Animal Behaviour, 84(6), 1565-1571. doi:10.1016/j.anbehav.2012.09.034

Charlton, B. D., Reby, D., \& McComb, K. (2007). Female perception of size-related formant shifts in red deer, Cervus elaphus. Animal Behaviour, 74(4), 707-714. doi:10.1016/j.anbehav.2006.09.021

Claessens, L. P. A. M. (2009). A cineradiographic study of lung ventilation in Alligator mississippiensis. Journal of Experimental Zoology Part A: Ecological Genetics and Physiology, 311A(8), 563-585. doi:10.1002/jez.530

Cott, H. B. (1961). Scientific results of an inquiry into the ecology and economic status of the Nile Crocodile (Crocodilus niloticus) in Uganda and Northern Rhodesia. The Transactions of the Zoological Society of London, 29(4), 211-356. doi:10.1111/j.1096-3642.1961.tb00220.x

Dartnall, H. J. A., \& Lythgoe, J. N. (1965). The spectral clustering of visual pigments. Vision Research, 5(4), 81-100. doi:/10.1016/0042-6989(65)90057-X

Di-Poï, N., \& Milinkovitch, M. C. (2013). Crocodylians evolved scattered multi-sensory micro-organs. EvoDevo, 4(1), 19. doi:10.1186/2041-9139-4-19

Dominguez-Laso, J. (2007). Relocation of crocodilians using magnets. Crocodile Specialist Group Newsletter, 27(3), 5-6.

Ferguson, M. W. J. (1981). The structure and development of the palate in Alligator mississippiensis. Archives of Oral Biology, 26(5), 427-443. doi:/10.1016/0003-9969(81)90041-8

Fischer, F. P. (1994). General pattern and morphological specializations of the avian cochlea. Scanning Microscopy, 8, 351-364.

Fleishman, L. J., Howland, H. C., Howland, M. J., Rand, A. S., \& Davenport, M. L. (1988). Crocodiles don't focus underwater. Journal of Comparative Physiology A, 163(4), 441-443. doi:10.1007/BF00604898 
Gans, C., \& Clark, B. (1976). Studies on ventilation of Caiman crocodilus (crocodilia: Reptilia). Respiration Physiology, 26(3), 285-301. doi:10.1016/0034-5687(76)90001-3

Garrick, L. D. (1975). Structure and pattern of the roars of Chinese alligators (Alligator sinensis fauvel). Herpetologica, 31(1), 26-31.

Garrick, L. D., \& Lang, J. W. (1977). Social signals and behaviors of adult alligators and crocodiles. American Zoologist, 17(1), 225-239. doi:10.1093/icb/17.1.225

Garrick, L. D., Lang, J. W., \& Herzog, H. A. (1978). Social signals of adult American alligators. Bulletin of the American Museum of Natural History, 160(3), 153-192.

Gleich, O., \& Manley, G. A. (2000). The hearing organ of birds and Crocodilia. In R. J. Dooling, R. R. Fay, \& A. N. Popper (Eds.), Comparative hearing: Birds and reptiles (pp. 70-138). New York, NY: Springer New York. doi:10.1007/978-1-4612-1182-2_3

Govardovskii, V., Chkheidze, N., \& Zueva, L. (1988). Morphofunctional investigation of the retina in the crocodilian caiman Caiman crocodilus. Sensory Systems, 1, 19-25.

Grap, N. J., Monzel, A. S., Kohl, T., \& Bleckmann, H. (2015). Crocodylus niloticus (Crocodilia) is highly sensitive to water surface waves. Zoology, 118(5), 320-324. doi:10.1016/j.zool.2015.03.004

Grigg, G. C., \& Kirshner, D. (2015). Biology and evolution of crocodylians. Ithaca, NY: Cornell University Press. doi:10.1071/9781486300679

Güntürkün, O. (2005). The avian 'prefrontal cortex' and cognition. Current Opinion in Neurobiology, 15(6), 686-693. doi:10.1016/j.conb.2005.10.003

Hansen, A. (2007). Olfactory and solitary chemosensory cells: Two different chemosensory systems in the nasal cavity of the American alligator, Alligator mississippiensis. BMC Neuroscience, 8(1), 64. doi:10.1186/1471-2202-8-64
Herzog, H. A., \& Burghardt, G. M. (1977). Vocalization in juvenile crocodilians. Zeitschrift Für Tierpsychologie, 44(3), 294-304.

Higgs, D. M., Brittan-Powell, E. F., Soares, D., Souza, M. J., Carr, C. E., Dooling, R. J., \& Popper, A. N. (2002). Amphibious auditory responses of the American alligator (Alligator mississipiensis). Journal of Comparative Physiology A: Neuroethology, Sensory, Neural, and Behavioral Physiology, 188(3), 217-223. doi:10.1007/s00359-002-0296-8

Hugall, A. F., Foster, R., \& Lee, M. S. Y. (2007). Calibration choice, rate smoothing, and the pattern of tetrapod diversification according to the long nuclear gene RAG-1. Systematic Biology, 56(4), 543-563. doi:10.1080/10635150701477825

Huggins, S. E., Parsons, L. C., \& Pena, R. V. (1968). Further study of the spontaneous electrical activity of the brain of Caiman sclerops: Olfactory lobes. Physiological Zoology, 41(3), 371-383. doi:10.1086/physzool.41.3.30155469

Hunt, R. H., \& Watanabe, M. E. (1982). Observations on maternal behavior of the American alligator, Alligator mississippiensis. Journal of Herpetology, 16(3), 235-239. doi:10.2307/1563716

Jackson, K., Butler, D. G., \& Youson, J. H. (1996). Morphology and ultrastructure of possible integumentary sense organs in the estuarine crocodile (Crocodylus porosus). Journal of Morphology, 229(3), 315-324. doi:10.1002/(SICI)1097-4687(199609)229:3<315 ::AID-JMOR6>3.0.CO;2-X

Jarvis, E., Güntürkün, O., Bruce, L., Csillag, A., Karten, H., Kuenzel, W., ... Butler, A. B. (2005). Avian brains and a new understanding of vertebrate brain evolution. Nature Reviews Neuroscience, 6(2), 151-159. doi:10.1038/nrn1606

Joanen, T., \& McNease, L. (1970). A telemetric study of nesting female alligators on rockefeller refuge, Louisiana. Annual Conference of the Southeastern Association of Fish and Wildlife Agencies, 24, 175-193. 
Kabadayi, C., \& Osvath, M. (2017). Ravens parallel great apes in flexible planning for tool-use and bartering. Science, 357(6347), 202-204. doi:10.1126/science.aam8138

Kis, A., Huber, L., \& Wilkinson, A. (2015). Social learning by imitation in a reptile (Pogona vitticeps). Animal Cognition, 18(1), 325-331. doi:10.1007/s10071-014-0803-7

Kofron, C. P. (1991). Courtship and mating of the Nile crocodile (Crocodylus niloticus). Amphibia-Reptilia, 12(1), 39-48. doi:10.1163/156853891X00310

Köppl, C., Gleich, O., Schwabedissen, G., Siegl, E., \& Manley, G. A. (1998). Fine structure of the basilar papilla of the emu: implications for the evolution of avian hair-cell types. Hearing Research, 126(1), 99-112. doi:10.1016/S0378-5955(98)00156-7

Krückert, K., Flachsbarth, B., Schulz, S., Hentschel, U., \& Weldon, P. J. (2006). Ethyl-branched aldehydes, ketones, and diketones from caimans (Caiman and Paleosuchus; Crocodylia, Reptilia). Journal of Natural Products, 69(6), 863-870. doi:10.1021/np0600797

Lang, J. W., Whitaker, R., \& Andrews, H. (1986). Male parental care in mugger crocodiles. National Geographic Research, 2(4), 519-525.

Laurens, H., \& Detwiler, S. R. (1921). Studies on the retina. The structure of the retina of Alligator mississippiensis and its photomechanical changes. Journal of Experimental Zoology, 32(2), 207-234. doi:10.1002/jez.1400320204

Leake, P. A. (1974). Central projections of the statoacoustic nerve in Caiman crocodilus. Brain, Behavior and Evolution, 10(1-3), 170-196. doi:10.1159/000124311

Leitch, D. B., \& Catania, K. C. (2012). Structure, innervation and response properties of integumentary sensory organs in crocodilians. Journal of Experimental Biology, 215(23), 42174230. doi:10.1242/jeb.076836
Luo, Z.-X. (2007). Transformation and diversification in early mammal evolution. Nature, 450, 1011. Retrieved from doi:10.1038/nature06277

Manley, G. A. (1970). Frequency sensitivity of auditory neurons in the Caiman cochlear nucleus. Zeitschrift Für Vergleichende Physiologie, 66(3), 251-256. doi:10.1007/BF00297828

Manley, G. A., \& Gleich, O. (1992). Evolution and specialization of function in the avian auditory periphery. In D. B. Webster, A. N. Popper, \& R. R. Fay (Eds.), The evolutionary biology of hearing (pp. 561-580). New York, NY: Springer New York. doi:10.1007/978-1-4612-2784-7_34

Morpurgo, B., Gvaryahu, G., \& Robinzon, B. (1991). Food preference, fish attractability and behavior manifested toward new feed in young nile crocodiles, Crocodylus niloticus. Physiology \& Behavior, 50(1), 1-4. doi:10.1016/0031-9384(91)90489-B

Murray, C. M., Russo, P., Zorrilla, A., \& McMahan, C. D. (2019). Divergent morphology among populations of the New Guinea crocodile, Crocodylus novaeguineae (Schmidt, 1928): Diagnosis of an independent lineage and description of a new species. Copeia, 107(3), 517-523. doi:10.1643/CG-19-240

Nagloo, N., Collin, S. P., Hemmi, J. M., \& Hart, N. S. (2016). Spatial resolving power and spectral sensitivity of the saltwater crocodile, Crocodylus porosus, and the freshwater crocodile, Crocodylus johnstoni. The Journal of Experimental Biology, 219(9), 1394-1404. doi:10.1242/jeb.135673

Nesbitt, S. J. (2011). The early evolution of Archosaurs: Relationships and the origin of major clades. Bulletin of the American Museum of Natural History, 2011(352), 1-292. doi:10.1206/352.1

Nickel, E. (1960). Untersuchungen über den Farbensinn junger Alligatoren. Zeitschrift Für Vergleichende Physiologie, 43(1), 37-47. doi:10.1007/BF00351201 
Papet, L., Grimault, N., Boyer, N., \& Mathevon, N. (2019). Influence of head morphology and natural postures on sound localization cues in crocodilians. Royal Society Open Science, 6(7), Article 190423. doi:10.1098/rsos.190423

Parsons, T. S. (1970). The nose and Jacobson's organ. In C. Gans \& T. S. Parson (Eds.), Biology of the reptilia, Volume 2 (pp. 99-191). New York, NY: Academic Press.

Pettigrew, J. D., \& Grigg, G. C. (1990). Avian pattern of connections for binocular vision in crocodiles. Proceedings of the Australian Neuroscience Society, 1(144).

Pooley, A. C., \& Gans, C. (1976). The Nile crocodile. Scientific American, 234(4), 114-125. doi:10.1038/scientificamerican0476-114

Rand, A. S., \& Dudley, R. (1993). Frogs in helium: The anuran vocal sac is not a cavity resonator. Physiological Zoology, 66(5), 793-806. doi:10.1086/physzool.66.5.30163824

Read, M. A., Grigg, G. C., Irwin, S. R., Shanahan, D., \& Franklin, C. E. (2007). Satellite tracking reveals long distance coastal travel and homing by translocated estuarine crocodiles, Crocodylus porosus. PLOS ONE, 2(9), e949. Retrieved from doi:10.1371/journal.pone.0000949

Reber, S. A. (2018). Crocodilia communication. In J. Vonk \& T. Shackelford (Eds.), Encyclopedia of animal cognition and behavior (pp. 1-10). Cham, Switzerland: Springer International. doi:10.1007/978-3-319-47829-6_950-1

Reber, S. A., Janisch, J., Torregrosa, K., Darlington, J., Vliet, K. A., \& Fitch, W. T. (2017). Formants provide honest acoustic cues to body size in American alligators. Scientific Reports, 7(1816), 1-11. doi:10.1038/s41598-017-01948-1

Reber, S. A., Nishimura, T., Janisch, J., Robertson, M., \& Fitch, W. T. (2015). A Chinese alligator in heliox: formant frequencies in a crocodilian. Journal of Experimental Biology, 218(15), 2442-2447. doi:10.1242/jeb.119552
Reese, A. M. (1921). The structure and development of the integumental glands of the crocodilia. Journal of Morphology, 35(3), 581-611. doi:10.1002/jmor.1050350303

Reese, A. M. (1945). The laryngeal region of Alligator mississippiensis. The Anatomical Record, 92(3), 273-277. doi:10.1002/ar.1090920308

Retzius, G. (1884). The auditory organ of vertebrates: morphological-histological studies / the auditory organ of reptiles, birds and mammals. Stockholm, Sweden: Samson and Wallin.

Richardson, K. C., \& Park, J. Y. (2001). The histology of the dorsal integumentary glands in embryonic and young Estuarine crocodiles, Crocodylus porosus and Australian Freshwater crocodiles, Crocodylus johnstoni. In G. C. Grigg, F. Seebacher, \& C. E. Franklin (Eds.), Crocodilian biology and evolution (pp. 180-187). Sydney, Australia: Surrey Beatty \& Sons.

Saint Girons, H. (1976). Histological data on the nasal cavity and its annexes in Crocodylus niloticus Laurenti and Caiman crocodilus (Linnaeus) (Reptilia, Crocodylidae). Zoomorphologie, 84(3), 301-318. doi:10.1007/BF01578698

Saunders, J. C., Duncan, R. K., Doan, D. E., \& Werner, Y. L. (2000). The middle ear of reptiles and birds. In R. J. Dooling, R. R. Fay, \& A. N. Popper (Eds.), Comparative hearing: Birds and reptiles. Springer handbook of auditory research (Vol. 13, pp. 13-69). New York, NY: Springer New York. doi:10.1007/978-1-4612-1182-2_2

Scharff, C., \& Petri, J. (2011). Evo-devo, deep homology and FoxP2: implications for the evolution of speech and language. Philosophical Transactions of the Royal Society of London. Series B, Biological Sciences, 366(1574), 2124-2140. doi:10.1098/rstb.2011.0001

Scott, T. P., \& Weldon, P. J. (1990). Chemoreception in the feeding behaviour of adult American alligators, Alligator mississippiensis. Animal Behaviour, 39, 398-400. doi:10.1016/S0003-3472(05)80887-5 
Seed, A., Emery, N., \& Clayton, N. (2009).

Intelligence in corvids and apes: A case of convergent evolution? Ethology, 115(5), 401-420. doi:10.1111/j.1439-0310.2009.01644.x

Shettleworth, S. J. (2009). The evolution of comparative cognition: Is the snark still a boojum? Behavioural Processes, 80(3), 210-217. doi:10.1016/J.BEPROC.2008.09.001

Shirley, M. H., Vliet, K. A., Carr, A. N., \& Austin, J. D. (2013). Rigorous approaches to species delimitation have significant implications for African crocodilian systematics and conservation. Proceedings of the Royal Society B: Biological Sciences, 281(1776), 20132483-20132483. doi:10.1098/rspb.2013.2483

Sillman, A. J., Ronan, S. J., \& Loew, E. R. (1991). Histology and microspectrophotometry of the photoreceptors of a crocodilian, Alligator missisippiensis. Proceedings of the Royal Society B: Biological Sciences, 243(1306), 93-98. doi:10.1098/rspb.1991.0016

Sneddon, H., Hepper, P. G., \& Manolis, C. (2000). Embryonic chemosensory learning in the saltwater crocodile Crocodylus porosus. In G. C. Grigg, F. Seebacher, \& C. E. Franklin (Eds.), Crocodilian biology and evolution (pp. 378-382). Chipping Norton, Australia: Surrey Beatty \& Sons.

Soares, D. (2002). An ancient sensory organ in crocodilians. Nature, 417(6886), 241-242. doi:10.1038/417241a

Somaweera, R., \& Shine, R. (2012). Australian freshwater crocodiles (Crocodylus johnstoni) transport their hatchlings to the water. Journal of Herpetology, 46(3), 407-411. doi:10.1670/11-056

Stevenson, C. (2019). Crocodiles of the world. London, England: New Holland.

Stoddart, D. M. (1979). External nares and olfactory perception. Experientia, 35(11), 1456-1457. doi:10.1007/BF01962780
Todd, N. P. M. (2007). Estimated source intensity and active space of the American alligator (Alligator mississippiensis) vocal display. The Journal of the Acoustical Society of America, 122(5), 2906-2915. doi:10.1121/1.2785811

Underwood, G. (1970). The eye. In C. Gans \& T. S. Parsons (Eds.), Biology of the reptilia (Vol. 2, pp. 1-97). New York, NY: Academic Press.

Van Meir, V., Boumans, T., De Groof, G., Van Audekerke, J., Smolders, A., Scheunders, P., ... Van der Linden, A. (2005). Spatiotemporal properties of the BOLD response in the songbirds' auditory circuit during a variety of listening tasks. NeuroImage, 25(4), 1242-1255. doi:/10.1016/j.neuroimage.2004.12.058

Vergne, A. L., Aubin, T., Martin, S., \& Mathevon, N. (2012). Acoustic communication in crocodilians: Information encoding and species specificity of juvenile calls. Animal Cognition, 15(6), 1095-1109. doi:10.1007/s10071-012-0533-7

Vergne, A. L., Aubin, T., Taylor, P., \& Mathevon, N. (2011). Acoustic signals of baby black caimans. Zoology, 114(6), 313-320. doi:10.1016/j.zool.2011.07.003

Vergne, A. L., Avril, A., Martin, S., \& Mathevon, N. (2007). Parent-offspring communication in the Nile crocodile Crocodylus niloticus: Do newborns' calls show an individual signature? Naturwissenschaften, 94(1), 49-54. doi:10.1007/s00114-006-0156-4

Vergne, A. L., \& Mathevon, N. (2008). Crocodile egg sounds signal hatching time. Current Biology, 18(12), R513-R514. doi:10.1016/j.cub.2008.04.011

Vergne, A. L., Pritz, M. B., \& Mathevon, N. (2009). Acoustic communication in crocodilians: From behaviour to brain. Biological Reviews of the Cambridge Philosophical Society, 84(3), 391-411. doi:10.11 11/j.1469-185X.2009.00079.x

Vliet, K. A. (1989). Social displays of the American alligator (Alligator mississippiensis). American Zoologist, 29(3), 1019-1031. doi:10.1093/icb/29.3.1019 
Vliet, K. A. (2001). Courtship behaviour of American alligators Alligator mississippiensis. In G. C. Grigg, F. Seebacher, \& C. E. Franklin (Eds.), Crocodilian biology and evolution (pp. 383-408). Chipping Norton, Australia: Surrey Beatty \& Sons.

von Düring, M. (1974). The ultrastructure of cutaneous receptors in the skin of Caiman crocodilus. In M. Schmeißer, H. Brettschneider, J. G. Widdicombe, H. Knoche, K. Addicks, G. Schmitt, ... D. Ottoson (Eds.), Symposium Mechanoreception: Unter der Schirmherrschaft der Rheinisch-Westfälischen Akademie der Wissenschaften (pp. 123-134). Wiesbaden, Germany: VS Verlag für Sozialwissenschaften. doi:10.1007/978-3-663-01719-6_10

von Düring, M., Karduck, A., \& Richter, H.-G. (1974). The fine structure of the inner ear in Caiman crocodilus. Zeitschrift Für Anatomie Und Entwicklungsgeschichte, 145(1), 41-65. doi:10.1007/BF00519125

Wald, G., Brown, P. K., \& Kennedy, D. (1957).

The visual system of the alligator. The Journal of General Physiology, 40(5), 703-713. doi:10.1085/jgp.40.5.703

Wang, X., Wang, D., Zhang, S., Wang, C., Wang, R., \& Wu, X. (2009). Why do Chinese alligators (Alligator sinensis) form bellowing choruses: A playback approach. The Journal of the Acoustical Society of America, 126(4), 2082-2087. doi:10.1121/1.3203667

Webb, G. J. W., Manolis, S. C., \& Cooper-Preston, H. (1990). Crocodile management and research in the Northern Territory: 1988-90. In Proceedings of the 10th Working meeting IUCN-SSC Crocodile Specialist Group (pp. 253-273). Gland, Switzerland: IUCN.

Weldon, P. J., Brinkmeier, W. G., \& Fortunato, H. (1992). Gular pumping responses by juvenile American alligators (Alligator mississippiensis) to meat scents. Chemical Senses, 17(1), 79-83. doi:10.1093/chemse/17.1.79

Weldon, P. J., \& Ferguson, M. W. J. (1993).

Chemoreception in crocodilians: anatomy, natural history, and empirical results. Brain, Behavior and Evolution, 41(3-5), 239-245. doi:10.1159/000113845
Weldon, P. J., \& McNease, L. (1991). Does the American alligator discriminate between venomous and nonvenomous snake prey? Herpetologica, 47(4), 403-406.

Weldon, P. J., Swenson, D. J., Olson, J. K., \& Brinkmeier, W. G. (1990). The American alligator detects food chemicals in aquatic and terrestrial environments. Ethology, 85(3), 191-198. doi:10.1111/j.1439-0310.1990.tb00399.x

Weldon, P. J., \& Wheeler, J. W. (2001). The chemistry of crocodilian skin glands. In G. C. Grigg, F. Seebacher, \& C. E. Franklin (Eds.), Crocodilian biology and evolution (pp. 286-296). Sydney, Australia: Surrey Beatty \& Sons.

Wever, E. G. (1978). The reptile ear: Its structure and function. Princeton, NJ: Princeton University Press.

Wever, E. G., \& Vernon, J. A. (1957). Auditory responses in the spectacled caiman. Journal of Cellular and Comparative Physiology, 50(2), 333-339. doi:10.1002/jcp.1030500213

Whyte, A., Yang, Z.-C., Tiyanont, K., Weldon, P. J., Eisner, T., \& Meinwald, J. (1999). Reptilian chemistry: Characterization of dianeackerone, a secretory product from a crocodile. Proceedings of the National Academy of Sciences, 96(22), 1224612250. doi:10.1073/pnas.96.22.12246

Wilkinson, A., Kuenstner, K., Mueller, J., \& Huber, L. (2010). Social learning in a non-social reptile (Geochelone carbonaria). Biology Letters, 6(5), 614-616. doi:10.1098/rsbl.2010.0092

Witmer, L. M., Ridgely, R. C., Dufeau, D. L., \& Semones, M. C. (2008). Using CT to peer into the past: $3 \mathrm{D}$ visualization of the brain and ear regions of birds, crocodiles, and nonavian dinosaurs. In H. Endo \& R. Frey (Eds.), Anatomical imaging: Towards a new morphology (pp. 67-87). Tokyo, Japan: Springer Japan. doi:10.1007/978-4-431-76933-0_6 